\title{
Mating Between Strains of the Yeasts Aessosporon salmonicolor and Sporobolomyces spp.
}

\author{
JACK W. FELL AND ADELE STATZELL TALLMAN \\ Rosenstiel School of Marine and Atmospheric Science, University of Miami, Miami, Florida 33149
}

\begin{abstract}
Although Aessosporon salmonicolor was described with a homothallic life cycle, mating studies of strains of A. salmonicolor and Sporobolomyces spp. demonstrated a heterothallic life cycle typical of other basidiomycetous yeasts.
\end{abstract}

van der Walt (4) described a homothallic sexual cycle in a strain (CBS 5937) of Sporobolomyces salmonicolor (Fischer et Brebeck) Kluyver et van Niel 1894 in which a diploid teliospore was formed by fusion of haploid mother and daughter cells. Teliospores were reported as thick-walled, lipid-rich cells that germinated to the haploid stage. Based on this life cycle and on a study of the deoxyribonucleic acid content of cells that suggested the presence of haploand diplophases (5), the genus Aessosporon van der Walt 1970 was described.

Bandoni et al. (1) reported mating between the type strains of Sporobolomyces hispanicus Pelaez et Ramirez 1956, Sporobolomyces odorus Derx 1930, and Sporobolomyces salmonicolor. The mating system was typical of heterothallic basidiomycetous yeasts in the genera Leucosporidium and Rhodosporidium. Conjugation between compatible mating types was followed by the formation of a mycelium with clamp connections and chlamydospores (presumably teliospores). Germination of the teliospores,

TABLE 1. Mating reactions of strains of Sporobolomyces spp. and A. salmonicolor ${ }^{\prime \prime}$

\begin{tabular}{|c|c|c|}
\hline \multirow[b]{2}{*}{ Strain } & \multicolumn{2}{|c|}{ Mating with: } \\
\hline & $\begin{array}{l}\text { S. odorus } \\
\text { UBC } 948\end{array}$ & $\begin{array}{l}\text { S. holsaticus } \\
\text { CBS } 2630\end{array}$ \\
\hline $\begin{array}{l}\text { A. salmonicolor CBS } \\
5937^{b}\end{array}$ & + & + \\
\hline S. salmonicolor CBS & + & + \\
\hline $\begin{array}{l}\text { S. salmonicolor var. } \\
\text { fisheri CBS } 6832^{b}\end{array}$ & + & + \\
\hline S. odorus UBC 949 & + & + \\
\hline S. odorus UBC 950 & + & + \\
\hline S. odorus 5Y & + & + \\
\hline S. odorus $7 \mathrm{Y}$ & + & + \\
\hline S. holsaticus CBS $1522^{h}$ & - & - \\
\hline S. hispanicus CBS $2873^{h}$ & + & + \\
\hline
\end{tabular}

"Sources: UBC cultures were from R. J. Bandoni, University of British Columbia, Vancouver, Canada; CBS cultures were from D. Yarrow, Centraalbureau voor Schimmelcultures, Delft, The Netherlands; cultures $5 \mathrm{Y}$ and $7 \mathrm{Y}$ were from $\mathrm{S}$. A. Meyer, Georgia State University, Atlanta.

${ }^{b}$ Type strain. which would complete the life cycle, was not observed. Bandoni et al. concluded that the three species were nonspecific and that the oldest name, $S$. salmonicolor, should be accepted.

We examined the possible relationship of Aessosporon salmonicolor to $S$. salmonicolor by mixing strains (Table 1) on corn meal agar at $18^{\circ} \mathrm{C}$. The results (Table 1 ) demonstrated two mating types; intermating within a mating type did not occur. Mating of Sporobolomyces holsaticus CBS 2630 or $S$. odorus UBC 948 with $A$. salmonicolor CBS 5937 resulted in the response reported (1) for other strains of Sporobolomyces. After 2 to 3 days there was the formation of a mycelium with clamps and teliospore-like structures (Fig. 1). Teliospore germination was not observed. The life cycle appears to be identical to the heterothallism reported in Leucosporidium and Rhodosporidium $(2,3)$. This does not preclude the possibility of a homothallic life cycle, as reported by van der Walt. It is our opinion, based on the heterothallic life cycle of this organism, that $A$. salmonicolor belongs to

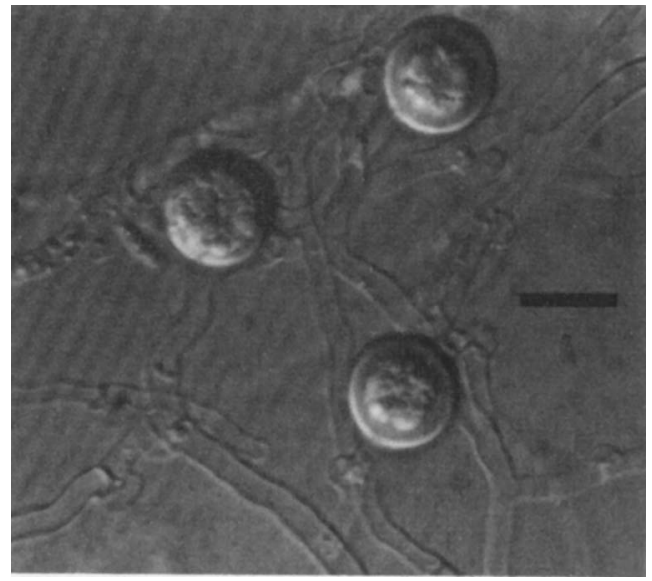

FIG. 1. Hyphae, clamps, and teliospores formed from a mating of $A$. salmonicolor $C B S 5937$ and $S$. odorus UBC 948. Nomarski differential phase contrast microscopy. Bar $=10 \mu \mathrm{m}$. 
the same heterothallic sexual species as $S$. salmonicolor, which includes the synonyms provided by Bandoni et al. $S$. holsaticus may or may not be included in this species. Although one strain of $S$. holsaticus (CBS 2630) demonstrated a mating response, the type strain (CBS 1522 ) was not sexually compatible with any of the strains listed in Table 1.

The systematics of these yeasts still requires clarification. Aessoporon is described as a sexual genus, and Sporobolomyces is an asexual genus. Final taxonomic decisions will require a determination of the complete life cycles of the yeasts in the two genera.

\section{ACKNOWLEDGMENTS}

This research was funded by the National Science Foundation through the Office of Systematic Biology.

\section{REPRINT REQUESTS}

Address reprint requests to: Dr. Jack W. Fell, Rosenstiel School of Marine and Atmospheric Science, University of Miami, 4600 Rickenbacker Causeway, Miami, FL 33149.

\section{LTERATURE CITED}

1. Bandoni, R. J., B. N. Johri, and S. A. Reid. 1975. Mating among isolates of three species of Sporobolomyces. Can. J. Bot. 53:2942-2944.

2. Fell, J. W., I. L. Hunter, and A. S. Tallman. 1973. Marine basidiomycetous yeasts (Rhodosporidium spp. n.) with tetrapolar and multiple allelic bioplar mating systems. Can. J. Microbiol. 19:643-657.

3. Lodder, J. 1970. The yeasts. North Holland Publishing Co., Amsterdam.

4. van der Walt, J. P. 1970. The perfect and imperfect states of Sporobolomyces salmonicolor. Antonie van Leeuwenhoek J. Microbiol. Serol. 36:45-55.

5. van der Walt, J. P., and M. J. Pitout. 1969. Ploidy differences in Sporobolomyces salmonicolor and Candida albicans. Antonie van Leeuwenhoek J. Microbiol. Serol. 35:227-231. 